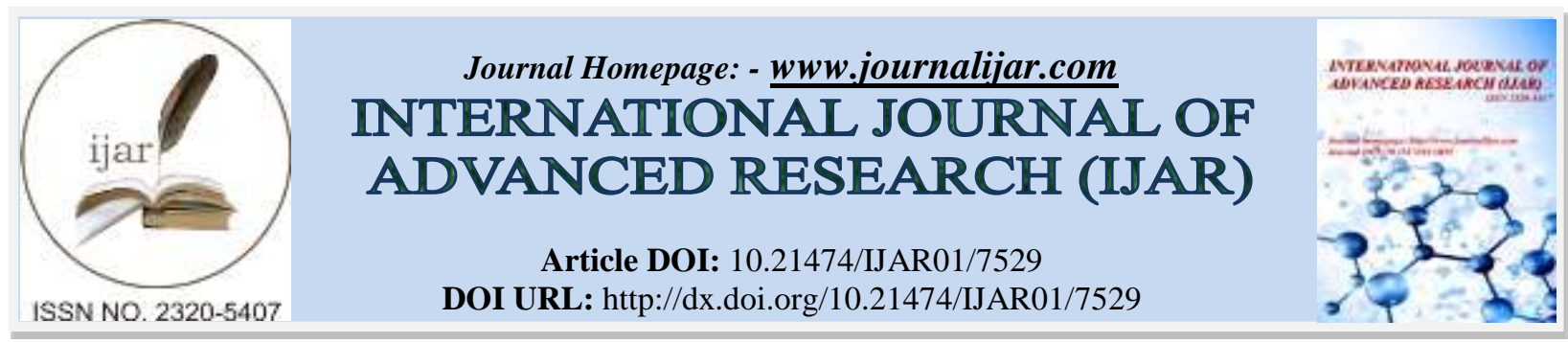

RESEARCH ARTICLE

\title{
THE STUDY OF PREVALENCE OF TUBERCULOSIS IN HIV INFECTED AND AIDS PATIENTS AND ITS CORRELATION WITH $\mathrm{CD}_{4}$ COUNT.
}

\author{
Saru kumar Debbarma ${ }^{1}$, Asis Debbarma ${ }^{2}$, H. Lokhendro Singh ${ }^{3}$, Taruni $\mathrm{Ng}^{4}$ and M. Kulachandra Singh ${ }^{4}$ \\ 1. Assistant Professor, Dept. of Medicine, Agartala Govt. Medical College, Kunjaban, Agartala, Tripura. \\ 2. Assistant Professor, Dept. of Biochemistry, Agartala Govt. Medical College, Kunjaban, Agartala, Tripura. \\ 3. Professor, Dept. of Microbiology, Regional Institute of Medical Sciences, Imphal, Manipur. \\ 4. Professor, Dept. of Medicine, Regional Institute of Medical Sciences, Imphal, Manipur.
}

\section{Manuscript Info}

(.........................

Manuscript History

Received: 10 June 2018

Final Accepted: 12 July 2018

Published: August 2018

Keywords:-

TB, HIV, AIDS, $\mathrm{CD}_{4}$, CSF, FNAC, Lymphadenitis, Immunodeficiency,

Mycobacterium.

\section{Abstract}

This study was conducted at Regional Institute of Medical Sciences, Imphal on 50 number of HIV/AIDS patients. Male comprised the majority of the cases $(80 \%)$ and maximum number of patients were in the age group between $31-40$ years of age (44\%) with an average age of 33.72 years. The most common route of transmission was intravenous drug use (54\%) followed by heterosexual contact (34\%). The most clinical features observed were fever > 1 month (68\%), weight loss $>10 \%$, body weight $(56 \%)$, cough $(36 \%)$, headache $(28 \%)$, oral thrush and neck stiffness (24\%) each and altered sensorium (20\%). Co-infection with tuberculosis (TB) was recorded in 52\% cases and it was more in patients with lower $\mathrm{CD}_{4}$ cell counts. In cerebrospinal Fluid (CSF) analysis protein was raised in $44 \%$ cases and reduced level of sugar was seen in $89 \%$ cases. In all the cases increased cell count with lymphocytic predominance was noted. Cryptococcus was detected in $56 \%$ cases but no Acid-Fast-Bacilli (AFB) was detected. Histopathological examination of fine needle cytology (FNAC) lymph node showed tubercular lymphadenitis in majority of the cases with positive AFB in few cases. An Extrapulmonary (61\%) manifestation of tuberculosis was more than the pulmonary $(27 \%)$ manifestations and the difference was more with lower $\mathrm{CD}_{4}$ cell counts $(\leq 50$ cells/cumm). However, the different clinical pattern of tuberculosis in relation to $\mathrm{CD}_{4}$ cell count was insignificant ( $p>0.05)$.

Copy Right, IJAR, 2018,. All rights reserved.

\section{Introduction:-}

Human Immunodeficiency Virus (HIV), the causative agent for Acquired Immunodeficiency syndrome (AIDS) is believed to have originated from simian viruses. The HIV-I and HIV-II are both cytopathic viruses belonging to the family of human retroviruses and the retroviridae lentiviridae ${ }^{(1)}$. Structurally, HIV possesses an outer glycoprotein coats and inner "core" proteins and genes. The HIV has nine genes. The three structural genes- gag, pol and env encodes for core protein p19, p24; the enzymes- protease, reverse transcriptase and integrase; envelope glycoprotein's- gp120 and gp41 respectively. The major regulatory genes, tat and rev encode proteins which are not assembled into the virus but are essential for replication of the virus in the cells. The four assessor genes nef, vif, vpr 
and vpu genes also codes for protein involved in different functions. HIV-II differs from HIV I as it contain VPx gene in place of VPu gene and it does not incorporate the cellular cyclophylin- $\mathrm{A}^{(7)}$.

Tuberculosis occurs after the inhalation of infective droplet nuclei containing Mycobacterium tuberculosis. The clinical manifestations of tuberculosis in HIV infected patients are quite varied and generally show different patterns depending on the level of the $\mathrm{CD}_{4}$ and $\mathrm{T}$ cell count. World Health Organization (WHO) estimates that one third of the world's population; 2 billion people are infected with M. tuberculosis. Infection rates are highest in Southeast Asia, China, India, Africa and Latin America ${ }^{(2)}$. HIV infects $\mathrm{CD}_{4} \mathrm{~T}$-lymphocytes predominantly. Depletion of $\mathrm{CD}_{4}$ T-lymphocytes results in immunodeficiency. The term AIDS refers to the last stage of HIV infection ${ }^{(3)}$. Tuberculosis is the commonest opportunistic infection in HIV infected patients in developing countries including India. The sero prevalence of HIV among tuberculosis patients in various parts of India has been increasing steadily

${ }^{(8)}$. Prevalence of M. tuberculosis and HIV co-infection worldwide was $18 \%$. The global burden of tuberculosis remains enormous ${ }^{(4)}$. The deadly partnership between HIV and tuberculosis is mutually reinforcing since active tuberculosis seems to enhance viral replication and accelerate the progression of AIDS via increased production of TNF, which is known to facilitate HIV replication in infected lymphocytes ${ }^{(9)}$.

Clinically, the useful way to classify HIV infection is based on the management implication of the patients with $\mathrm{CD}_{4}$ cell count of the patients. Grade-I included those patients with $\mathrm{CD}_{4}$ cell counts greater than or equal to $500 /$ cumm of blood, Gr.-II are those with $\mathrm{CD}_{4}$ counts between 200 and 500/cumm, and Gr.-III are those with $\mathrm{CD}_{4}$ counts of less than 200/cumm. It was described that the suppressed immunity is the cause of developing opportunistic infections, malignancies among HIV/AIDS, the prime cause of mortality and morbidity. However, early detection and medical intervention retarded the disease progression and improved survival ${ }^{(10)}$. Generally, the $\mathrm{CD}_{4}$ cells in blood falls gradually and progressively so that there is a long period of clinical latency before the development of AIDS which may be around 10 years in case of HIV-I infection or even longer in HIV-II infection ${ }^{(5)}$.

\section{Aims And Objectives:-}

a. To find out the prevalence of tuberculosis in patients with HIV infected and AIDS.

b. To rule out the clinical features of tuberculosis in HIV infected and AIDS positive tuberculosis patients.

c. To find out $\mathrm{CD}_{4}$ count in correlation with tuberculosis in AIDS patients.

\section{Materials And Methods:-}

The study was carried out in the department of Medicine in collaboration with the department of Microbiology, Regional Institute of Medical Sciences (RIMS), Imphal, Manipur during the period of September 2003 to August 2005. Fifty cases of HIV infected and AIDS admitted to the Medicine ward were taken as study group. In order to diagnose pulmonary tuberculosis 3 early morning sputum sample were collected for 3 consecutive days and were sent to Microbiology department for detection of Acid Fast Bacilli in the stained smear ${ }^{(11)}$. On the other hand, for diagnosis of HIV infection and AIDS, patients were referred to National Reference Laboratory, department of Microbiology, RIMS, Imphal. Accordingly, pretest counseling as well as patient's consent was taken. Then $05 \mathrm{ml}$ blood was drawn aseptically from the patient following standard operative procedure. The blood was tested as to find out HIV antibodies by ELISA/Rapid/Simple test. Post test counseling was also done to those patients who were found to be HIV seropositive/AIDS patients ${ }^{(12)}$.

In case of $\mathrm{CD}_{4}$ count, $3 \mathrm{ml}$ of blood was collected in an EDTA vial $\left(\mathrm{K}_{3}\right.$ EDTA Vacutainer vial) and $\mathrm{CD}_{4}$ count of the sample was carried out in the department of Microbiology, RIMS by Fluorescence Activated Cell Sorter ${ }^{(6)}$.

\section{Results And Observations:-}

Fifty number of HIV/AIDS patients who were admitted in Medicine ward of RIMS, Imphal were included in this study and the work was carried out during the period between September 2003 and August 2005.

Table No. 1:- Age and Sex Distribution of cases (Study Group n=50)

\begin{tabular}{|l|l|l|l|l|}
\hline \multirow{2}{*}{ Age group in years } & Number of patients & \multirow{2}{*}{ Total } & \multirow{2}{*}{ Percentage (\%) } \\
\cline { 2 - 5 } & Male & Female & & \\
\hline $13-20$ & 0 & 1 & 1 & 2 \\
\hline $21-30$ & 14 & 3 & 17 & 37 \\
\hline $\mathbf{3 1 - 4 0}$ & $\mathbf{1 9}$ & $\mathbf{3}$ & $\mathbf{2 2}$ & $\mathbf{4 4}$ \\
\hline
\end{tabular}




\begin{tabular}{|l|l|l|l|l|}
\hline $41-50$ & 7 & 3 & 10 & 20 \\
\hline Total & 40 & 10 & 50 & 100 \\
\hline
\end{tabular}

In our study, it was revealed that out of total 50 HIV seropositive/AIDS cases (belonging to 13 to 50 years of age), $80 \%$ were males and $20 \%$ were females. The most commonly affected age group was found to be 31 to 40 years of age group (44\%) with an average age of 33.72 years (Table No.1).

Table No.2:- Showing Distribution of Risk Behaviors (Study Group n=50)

\begin{tabular}{|l|l|l|l|l|}
\hline \multirow{2}{*}{ Source of Infection } & No. of Cases & Percentage & \multirow{2}{*}{$(\boldsymbol{\%})$} \\
\cline { 2 - 4 } & Male & Female & $\mathbf{5 4}$ & \\
\hline IDUs & $\mathbf{2 7}$ & $\mathbf{0}$ & 34 & \\
\hline Heterosexual & 10 & 7 & 2 & \\
\hline Homosexual & 1 & 0 & 10 & \\
\hline Blood transfusion & 2 & 3 & & \\
\hline
\end{tabular}

It was observed that the most common route of transmission of HIV infection was intravenous drug use (IUD) which constituted $27(54 \%)$ patients and heterosexual contact carries the second most common route of transmission constituting 17 patients(34\%) when $\mathrm{n}=50$ (Table No.2).

Table No. 3:- Distribution of Signs and Symptoms (Study Group n=50)

\begin{tabular}{|l|l|l|}
\hline Signs and Symptoms & No. of cases & $\begin{array}{l}\text { Percentage } \\
(\mathbf{\%})\end{array}$ \\
\hline Headache & 14 & 28 \\
\hline Fever & $\mathbf{3 4}$ & $\mathbf{6 8}$ \\
\hline Vomiting & 8 & 16 \\
\hline Convulsion & 2 & 4 \\
\hline Cough & 18 & 36 \\
\hline Diarrhea & 3 & 12 \\
\hline Neck stiffness & 12 & 24 \\
\hline Oral thrush & 12 & 24 \\
\hline Weight loss & $\mathbf{2 8}$ & $\mathbf{5 6}$ \\
\hline Altered sensorium/coma & 10 & 20 \\
\hline Lymphadenopathy & 4 & 8 \\
\hline Para umbilical lump & 3 & 6 \\
\hline Jaundice & 4 & 8 \\
\hline Hemiplegia & 2 & 4 \\
\hline Distension of abdomen & 4 & 8 \\
\hline Haemoptysis & 4 & 8 \\
\hline Breathlessness & 9 & 18 \\
\hline Irregular menstruation & 1 & 2 \\
\hline
\end{tabular}

The most common clinical features observed among the patients in the present study were fever in $34(68 \%)$ patients followed by weight loss in $28(56 \%)$ patients. Cough was complained by $18(36 \%)$ patients and headache by 14 (28\%) patients. However, out of 10 female patients, only one gave the history of irregular menstruation (Table No.3).

Table No. 4:- Showing CSF Findings (Study Group n=18)

\begin{tabular}{|c|c|c|c|c|}
\hline Sample & Range & No. of cases & Percentage (\%) & $\mathbf{p}$ \\
\hline \multirow[t]{3}{*}{ Protein(mg/dl) } & $\leq \mathbf{2 0}$ & 2 & 11 & \multirow[t]{3}{*}{$>0.05$} \\
\hline & $21-40$ & 8 & 44 & \\
\hline & $\geq 41$ & 8 & 44 & \\
\hline \multirow[t]{3}{*}{ Sugar(mg/dl) } & $\leq 40$ & 16 & 89 & \multirow[t]{3}{*}{$<0.01$} \\
\hline & $41-80$ & 2 & 11 & \\
\hline & $\geq 81$ & 0 & 0 & \\
\hline
\end{tabular}




\begin{tabular}{|c|c|c|c|c|}
\hline \multirow[t]{3}{*}{ TLC (cells $/ \mathrm{mm}^{3}$ ) } & $5-100$ & 12 & 67 & \multirow[t]{3}{*}{$<0.01$} \\
\hline & $100-300$ & 4 & 22 & \\
\hline & $>300$ cells & 2 & 11 & \\
\hline \multirow[t]{2}{*}{ DLC $\left(\right.$ cells $\left./ \mathrm{mm}^{3}\right)$} & $\begin{array}{l}\text { Lymphocyte } \\
>90 \% \\
<90 \%\end{array}$ & $\begin{array}{l}15 \\
3\end{array}$ & $\begin{array}{l}83 \\
17\end{array}$ & $<0.001$ \\
\hline & $\begin{array}{l}\text { Polymorphs } \\
>10 \% \\
<10 \%\end{array}$ & $\begin{array}{l}6 \\
12\end{array}$ & $\begin{array}{l}33 \\
67\end{array}$ & $>0.05$ \\
\hline \multirow[t]{2}{*}{ Cryptococcus } & Positive & 10 & 56 & \multirow[t]{2}{*}{$>0.05$} \\
\hline & Negative & 8 & 44 & \\
\hline \multirow[t]{2}{*}{ Acid Fast bacilli } & Positive & 0 & 0 & \multirow[t]{2}{*}{$\begin{array}{ll}--- \\
\end{array}$} \\
\hline & Negative & 18 & 100 & \\
\hline
\end{tabular}

In Cerebrospinal fluid (CSF) finding of the patients, protein is found to be raised; it is in the range of $21-40 \mathrm{mg} / \mathrm{dl}$ in $08(44 \%)$ patients, $\geq 41 \mathrm{mg} / \mathrm{dl}$ in $08(44 \%)$ patients and $\leq 20 \mathrm{mg} / \mathrm{dl}$ in $2(11 \%)$ patients. Sugar is below $40 \mathrm{mg} / \mathrm{dl} \mathrm{in}$ $16(89 \%)$ patients and $2(11 \%)$ patients are in the range of $41-80 \mathrm{mg} / \mathrm{dl}$. Total leukocyte count was in the range of 5100 cells $/ \mathrm{mm}^{3}$ in $12(67 \%)$ patients, $100-300$ cells $/ \mathrm{mm}^{3}$ in $4(22 \%)$ patients and more than 300 cells $/ \mathrm{mm}^{3} \mathrm{in} 2(11 \%)$ patients. $15(83 \%)$ patients had lymphocyte count more than $90 \%$ and $3(17 \%)$ patients had lymphocyte count less than $90 \%$. Polymorphonuclear leukocyte was more than $10 \%$ in $6(33 \%)$ cases and less than $10 \%$ in 12 (67\%) cases. Cryptococcus was detected in $10(56 \%)$ patients and Acid Fast Bacilli was not at all detected in CSF (Table No. 4).

Table No. 5:- Showing FNAC Findings of Lymph Nodes According to Pathology $(\mathrm{n}=14)$

\begin{tabular}{|l|l|l|l|}
\hline HPE/FNAC Findings & No. of patients & Percentage (\%) & p \\
\hline TB Lymphadenitis with positive AFB & $\mathbf{5}$ & $\mathbf{3 6}$ & \\
\cline { 1 - 3 } TB Lymphadenitis with negative AFB & 4 & 29 & \multirow{2}{*}{$>0.05$} \\
\hline Reactive hyperplasia & 2 & 14 & \\
\hline Non-specific features & 3 & 21 & \\
\hline
\end{tabular}

In Table No. 5 shows histopathological examination of FNAC report of lymph node examination where tubercular lymphadenitis positive AFB was detected in 5 patients $(36 \%)$.

TB lymphadenitis and negative AFB was found in 4 patients (29\%). Reactive hyperplasia and non specific features were more found in 2 and 3 patients respectively where $\mathrm{P}>0.05$.

Table No. 6:- Showing clinical pattern of tuberculosis in relation to $\mathrm{CD}_{4}$ count

\begin{tabular}{|c|c|c|c|c|}
\hline $\begin{array}{l}\mathrm{CD}_{4} \quad \text { count } \\
\text { (cells/cumm) }\end{array}$ & $\begin{array}{ll}\text { Pulmonary } & \text { TB } \\
\text { (Nos./percentage) } & \end{array}$ & $\begin{array}{l}\text { Extrapulmonary } \\
\text { Nos./percentage }\end{array}$ & $\begin{array}{lr}\text { Pulmonary } & \text { and } \\
\text { extrapulmonary } & \text { TB } \\
\text { (Nos./percentage) } & \\
\end{array}$ & p \\
\hline $01-50$ & $03(11)$ & $10(38)$ & $1(3)$ & \multirow{6}{*}{$>0.5$} \\
\hline $51-100$ & $01(3)$ & $01(3)$ & $1(3)$ & \\
\hline $101-200$ & $01(3)$ & 05 (19) & $1(3)$ & \\
\hline $201-300$ & $01(3)$ & $00(0)$ & $0(0)$ & \\
\hline$\geq 301$ & $01(3)$ & $00(0)$ & $0(0)$ & \\
\hline Total & $07(27)$ & $16(61)$ & $3(12)$ & \\
\hline
\end{tabular}

The clinical pattern of tuberculosis in relation to $\mathrm{CD}_{4}$ count shows pulmonary $\mathrm{TB} 3(11 \%)$, extra pulmonary $\mathrm{TB} 10$ $(38 \%)$ and pulmonary plus extra pulmonary $\mathrm{TB} 1(3 \%)$ in the $\mathrm{CD}_{4}$ cell range of $1-50$ cells/cumm. Besides, 01 (3\%) pulmonary, $05(19 \%)$ extra pulmonary and $01(3 \%)$ pulmonary plus extra pulmonary cases are noticed in the $\mathrm{CD}_{4}$ cell range $101-200$ cells/cumm. On the other hand, only one $(3 \%)$ pulmonary case was observed in $\mathrm{CD}_{4}$ cell counts $\geq 301$ cells/cumm. Hence, number of pulmonary, extra pulmonary and pulmonary plus extra pulmonary tuberculosis were $7(27 \%), 16(61 \%)$ and $3(12 \%)$ respectively (Table No. 6).

\section{Discussion:-}

In our study, the highest numbers of HIV seropositive cases were found in the age group of 31-40 years comprising $44 \%$ where males are infected predominantly (80\%) this could be due to lack of awareness about HIV/AIDS among 
the young adults. It implies that age and sex was not a dependable factor for causing HIV infection/AIDS, when it comes to risk behaviors. In our study, affected age group with HIV/AIDS showed more specific than the previous report of Mohanty KC and Basher P.M.M. (1994) where they have reported that more than $90 \%$ of cases were in the age group of 15 and 45 years ${ }^{(13)}$. Intravenous drug users are the most common route of transmission and males are mostly affected with HIV/AIDS. Negligence, behaviors and poor knowledge about the transmission of HIV could probably the reason of affecting more among males.

Prolonged fever, weight loss, cough etc. were noticed to be the most common comprising of $68 \%$, $56 \%$, and $36 \%$ of cases respectively. These could be because of having underlying disorder, opportunistic infections and HIV replications causing low immunity system within the body. However, our result is closely matching with the findings of Sara Chacko and John TJ (1995) where it was reported that $62 \%$ of their patients had fever and $31 \%$ had significant weight loss in their review of 61 AIDS cases from South India ${ }^{(14)}$.

FNAC report with lymphadenopathy showed tubercular lymphadenitis in $9(64 \%)$ patients with positive AFB in 5 $(36 \%)$ patients. The variation of number of patients is found to be statistically insignificant ( $\mathrm{p}>0.05)$. This is almost similar with the findings of Sengupta D and Shivlal (1993) ${ }^{(15)}$.

Previous studies had also revealed that tuberculosis is the commonest life threatening opportunistic infection. In our study too high level of tubercular infection (52\%) was recorded. As HIV infection causes immunosuppressant, the tubercular infection become overt disease even in higher $\mathrm{CD}_{4}+\mathrm{T}$-lymphocyte count. Thereby in this study extra pulmonary TB $(61 \%)$ was more than primary TB $(27 \%)$ and the difference was more with lower $\mathrm{CD}_{4}+\mathrm{T}-\mathrm{lymphocyte}_{\mathrm{l}}$ count. However, clinical pattern of TB in relation to $\mathrm{CD}_{4}$ cell count was insignificant $(\mathrm{p}>0.05)$.

\section{Conclusion:-}

Out of 50 numbers of seropositive/AIDS patients, males are predominant and most commonly affected age group was found to be 31 to 40 years (44\%) with the average age of 33.72 years. Intravenous drug use was shown as most common route of transmission of HIV infection (54\%). Among symptoms and signs fever was noticed to be most common followed by weight loss, cough, headache, neck stiffness and so on. During CSF analysis most importantly, the detection of Cryptococcus was found to be $56 \%$ of total cases where no Acid Fast Bacilli was detected. Histopathological examination of FNAC lymph node showed tubercular lymphadenitis in majority of the cases with positive AFB (36\%). Co-infection with TB was found in $52 \%$ cases and it was more with lower $\mathrm{CD}_{4}$ cell counts. Extra pulmonary TB was more than the pulmonary TB and this difference was more with lower/decreasing $\mathrm{CD}_{4}$ cell counts. The different clinical pattern of TB in relation to $\mathrm{CD}_{4}$ cell count was found to be insignificant.

Larger sample size studies may however be carried out as to find out further information and better understanding in this regard.

\section{Acknowledgement:-}

The authors are indebted and grateful to the department of Medicine and Microbiology, RIMS, Imphal for all the logistic supports and cooperation. Special thanks and gratitude also goes to all the patients who have participated in this study, without whom, this venture would never have been completed. 


\section{References:-}

1. Anthony S Fauci and Clifford LH: Human Immunodeficiency Virus (HIV) disease, AIDS and related disorders, Harrison's Principles of Internal Medicine, Eugene Braunwald: Mc Graw Hill, New York, $15^{\text {th }}$ Edn., 18521913, 2001.

2. Jeffry R Stroke and Flor Munoz: Mycobacterial infection, Nelson Text Book of Pediatrics; Rechard E. Behrman, Rober M. Kliegman and Hal B. Jenson: W.B. Saunders Company, Philadelphia, $16^{\text {th }}$ Edn., 1, 885$897,2000$.

3. Vogel J and Joy G: "Acquired immunodeficiency syndrome" Encyclopedia of Microbiology; AC-Joshua Lederberg, Academic Press INC, New York, Vol-I, 17-28, 1992.

4. Dye C, Scheele S, Dolin P, Pathania V and Raviglione MC: Consensus statement on global burden of Tuberculosis: estimated incidence, prevalence and mortality by country, WHO Global Surveillance Project, JAMA; 292: 677-686, 1999.

5. Barlett JG: CD4 cell counts, the John Hopkins Hospital guides to medical case of patients with HIV infection; Wilkins, Baltimore Maryland, USA, 4: 25-29, 1994.

6. Grinar PF, Mayewski RJ, Musklin AI and Greenland P: Selection and interpretation of diagnostic tests and procedures, Ann. Intern. Med., 94, 557, 1991.

7. Luzzi GA, Peto TEA, Weiss RA and Conlon CP: HIV and AIDS, Oxford Text Book of Medicine, David A. Warrel: Oxford University Press, New York, $4^{\text {th }}$ Edn., 423-442, 2003.

8. Cherian T and Verghese VP: Tuberculosis with human immunodeficiency virus infection, Indian J. Pediatrics; 67(2 Suppl.): 47-52, 2000.

9. Peter F, Alan B, Paul T and Dixe E: Tuberculosis in patients with human immunodeficiency virus infection, NEJM; 324 (23): 1644-1650, 1991.

10. Steger KA: Epidemiology, Natural history and staging, HIV infection a clinical manual; Libman II and Withburg RA, Little Brown and Company, Boston (USA), 2: 3-20, 1993.

11. Raviglione Mario C and O'Brien Richard J: Tuberculosis, Harrison's Principles of Internal Medicine; Eugene Braunwald, Mc Graw Hill, New York, 15 ${ }^{\text {th }}$ Edn., 1024-1035, 2001.

12. Betty A Forbes: Laboratory Method in Basic Virology, Diagnostic Microbiology; Bailey and Scott: St. Louis, Missouri 63146, 10 $0^{\text {th }}$ Edn., 963-1028, 1998.

13. Mohanty KC, Basheer P.M.M.: Changing trend of HIV infection and tuberculosis in a Bombay area since 1988, Indian Journal of Tuberculosis; 41:147-150, 1994.

14. Sara Chacko and John TJ: Clinical profile of AIDS cases in India: A review of 61 cases, JAPI; Vol.43 No.8: 535-538, 1995.

15. Sengupta D and Shivlal: Opportunistic infection in AIDS, JIMA: Special issue on AIDS; 41-43, 1993. 